\title{
Effect of the Rootstock on Certain Fruit Characters of the Chironja ${ }^{1}$
}

\author{
Agripino Pérez and Ramón Bosque Lugo²
}

\section{INTRODUCTION}

The effect of the rootstock on the growth, development, nutrient content of the leaves, and dry matter composition of grafted citrus trees has been reported $(7,9,10)$. Parker and Jones (6) and Bitters and Batchelor (1) reported that the rootstock affects the fruit size of the orange. Ting et al. (10) reported two varieties of grapefruit grafted on rough lemon rootstock in which the color of the flesh was significantly richer than when grafted on sour orange. Ting and Deszyck (11) found that sour orange rootstock produced grapefruits of a lighter color and lower in lycopene, but higher in $\beta$ carotene than did rough lemon rootstock. These findings suggest that other fruit characters might well be affected by rootstock.

Chironja is a new citrus fruit discovered in Puerto Rico. The fruit has been described $(4,5)$ as globose to pyriform in shape, with the bore or stem end slightly to prominently collared and depressed. The inner white rag (albedo) does not have the bitter taste of the grapefruit, but rather the pleasing sweetness of the orange, and combines the flavor of both.

This paper reports the effects of native grapefruit, sour orange, and Cleopatra mandarine rootstock on fruit weight, peel weight, number of seeds and segments (carpcls) per fruit, and total soluble solids (Brix) of the chironja.

\section{MATERIALS AND METHODS}

Chironja trees were grafted on the above-mentioned rootstocks and planted in 1957 on Alonso and Coto clay soils at the Adjuntas and Isabela Agricultural Experiment Substations, respectively, at a distance of 20 feet by 20 feet. Each tree was fertilized during the first year with 1 pound of a 12-6-8 commercial fertilizer; thereafter, the amount of fertilizer was increased at the rate of 1 pound per year to the fifth year when each tree was given 10 pounds in two 5-pound applications per year.

Diseases and insects were controlled as needed. The Isabela experiment was irrigated during prolonged dry weather.

Twenty fruits collected at random around the canopy of each tree during

1 Manuscript submitted to Editorial Board October 7, 1971.

2 Assistant Agronomist, Isabela Substation and Associate Agronomist in Charge, Adjuntas Substation, Agricultural Experiment Station, Mayagüez Campus, University of Puerto Rico, Río Piedras, P.R. 
the seasons of 1962 and 1963 were taken to the laboratory, where each fruit was measured and recorded within 24 hours after harvesting.

The data were analyzed as $t$-test comparisons for unequal numbers of observations because of the unequal number of trees per rootstock and the lack of randomization in the planting. The Adjuntas experiment consisted of 30, 6, and 13 trees grafted on native grapefruit, sour orange, and Cleopatra mandarine rootstocks, respectively. The Isabela experiment consisted of 33 trees grafted on native grapefruit and 15 on sour orange rootstocks.

\section{RESULTS}

\section{FRUIT WEIGHT}

The mean weights of the fruits harvested during 1962 at the Adjuntas experiment from chironja trees grafted on grapefruit, sour orange, and Cleopatra mandarine rootstocks, as shown in figure 1, were 1.06, 0.95, and 0.94 pounds, respectively. The fruits from trees grafted on grapefruit rootstocks were significantly heavier, at the 1-percent level, than those from trees grafted on Cleopatra mandarine rootstock, and at the 5-percent level, heavier than those from trees grafted on sour orange rootstock. There was no significant difference between the mean weights of fruit grown on sour orange and Cleopatra mandarine rootstocks.

The mean weights of the fruits harvested at the 1963 Adjuntas experiment from chironja trees grafted on grapefruit, sour orange, and Cleopatra mandarine rootstocks, as shown in fig. 1 , were $0.96,0.81$, and 0.85 pounds, respectively. The differences between the chironja fruits grafted on grapefruit and the other two rootstocks were highly significant. As in 1962, the difference between sour orange and Cleopatra mandarine rootstocks was non-significant.

At the Isabela experiment, the mean weights of the fruits from chironja trees grafted on grapefruit were 0.90 and 0.85 pounds during 1962 and 1963 , respectively, as compared to the fruits from trees grafted on sour orange rootstock, which was 0.86 and 0.81 pounds during both years. These differences between rootstocks were non-significant.

The results of this study agree with those of Bitter and Batchelor (1) and Parker and Jones (6) who reported that the rootstocks of Valencia and Washington Navel oranges affect fruit size.

\section{PEDL WEIGHT}

The mean peel weights of the fruits harvested at the Adjuntas experiment from chironja trees grafted on grapefruit, sour orange and Cleopatra mandarine rootstocks in 1962 were $0.20,0.21$, and 0.18 pounds, respectively, as shown in figure 1 . There was no significant difference between grapefruit 

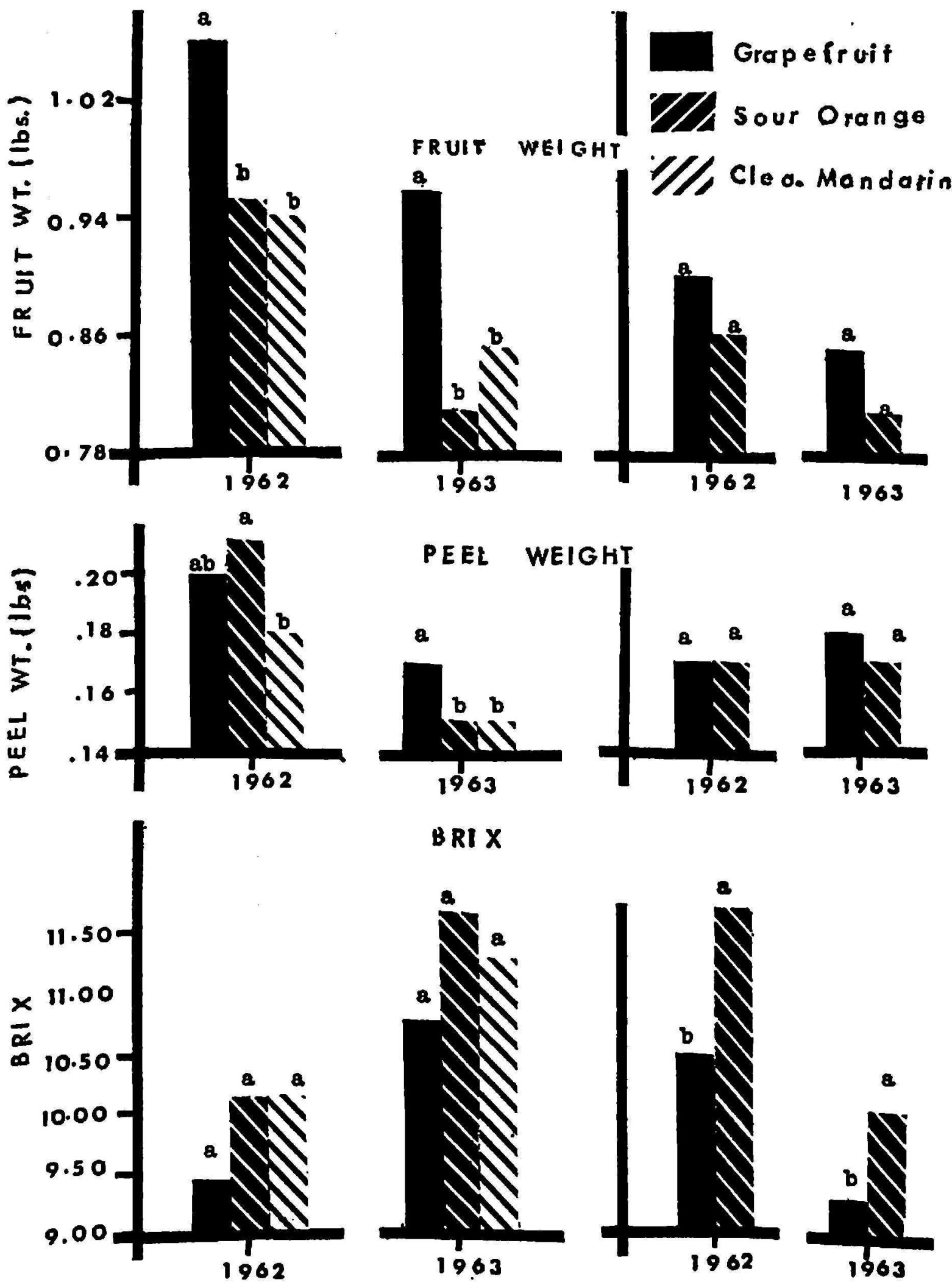

B RI X

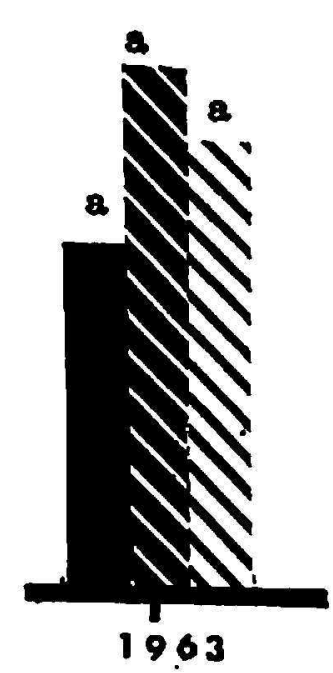

ADJUNTAS

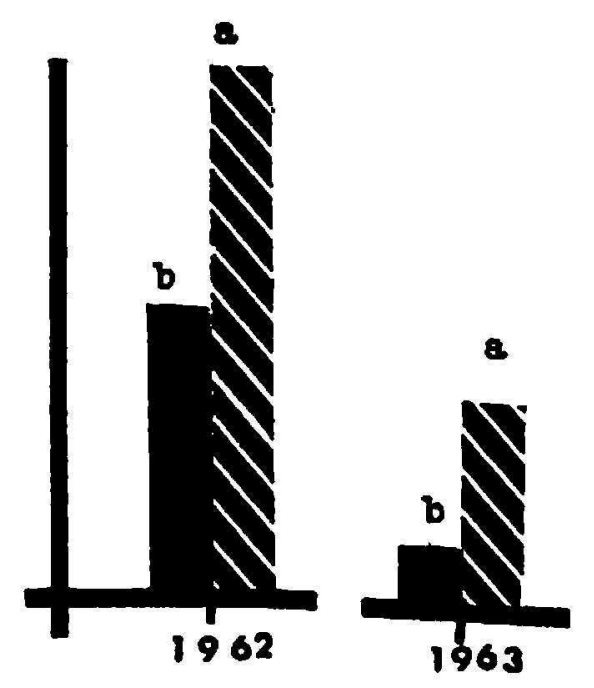

ISAB ELA

Fig. 1. Effect of grapefruit, sour orange, and Cleopatra mandarine rootstocks on fruit weight, peel weight, and ${ }^{\circ}$ Brix of the chironja during 2 years, at Adjuntas and Isabela. Means with different letters are significantly different at a probability level of less than 0.05 . 
and sour orange rootstocks, or between grapefruit and Cleopatra mandarine rootstocks. The difference between the sour orange and Cleopatra mandarine rootstock was significant at the 5-percent level. Figure 1 also shows that mean peel weights for 1963 were $0.17,0.15$, and 0.15 pounds for chironja grafted on grapefruit, sour orange, and Cleopatra mandarine rootstocks, respectively. The peel weights of the fruits from grapefruit rootstock was significantly greater than those from sour orange and Cleopatra mandarine. The peel weights of chironja grafted on sour orange and Cleopatra mandarine rootstocks were practically the same. The mean peel weight, like the fruit weight, was heavier during 1962 than 1963.

The peel weight of the fruit at the Isabela experiment was practically the same for the two rootstocks studied, without significant differences being noted during the 2-year study.

\section{NUMBER OF SEEDS AND SEGMENTS (CARPELS) PER FRUIT}

The number of seeds and segments (carpels) per fruit were not significantly influenced by any of the rootstocks studied.

\section{BRIX}

The mean Brix values (refractometer readings) of the fruit harvested at the Adjuntas experiment from chironja trees grafted on grapefruit, sour orange, and Cleopatra mandarine rootstocks were 9.47, 10.13 and 10.16 during 1962 , and $10.79,11.71$, and 11.30 during 1963 , respectively, as shown in figure 1 . These differences were not significant.

Figure 1 also shows that the mean Brix values in the case of grapefruit rootstock at the Isabela experiment during 1962 and 1963 were 10.5 and 9.31, respectively, as compared to sour orange rootstock in which it was 11.7 and 9.98 during both years. The difference between the two rootstocks during 1962 was significant at the 1-percent level and in 1963 at the 5-percent level.

\section{DISCUSSION}

At Adjuntas, grapefruit rootstock proved superior to sour orange and Cleopatra mandarine in respect to fruit weight in both years 1962 and 1963, and in respect to peel weight in 1963. Grapefruit rootstock thus should be preferred to the other two in this region. At Isabela, however, sour orange rootstock proved superior to grapefruit in respect to sweetness, and without fruit or peel weight differences. Sour orange therefore, should be preferred to grapefruit as rootstock for grafting chironja in this area.

\section{SUMMARY}

Chironja trees grafted on native grapefruit, sour orange, and Cleopatra mandarine rootstock were planted on Alonso clay and Coto clay at Adjuntas 
and Isabela Substations, respectively. Only native grapefruit and sour orange rootstocks were compared at Isabela.

The experiments were conducted for the purpose of determining the possible effect of the three rootstocks on fruit weight, peel weight, number of seeds and segments (carpels) per fruit, and refractometer readings of the fruit (Brix) harvested from the grafted chironja trees. The most important results obtained were:

Trees at Adjuntas grafted on grapefruit rootstock yielded heavier chironja fruits in 1962 and 1963, and a heavier peel in 1963, than those grafted on sour orange or Cleopatra mandarine rootstocks. In 1962, peel weights of chironja fruits from trees grafted on sour orange exceeded those obtained from trees grafted on mandarine rootstock.

Fruits from chironja trees at the Isabela experiment grafted on sour orange rootstock had a significantly higher Brix than those from trees grafted on grapefruit rootstock, but no significant differences occurred among the other characters studied.

No significant differences were found between chironja fruits from trees grafted on any of the three rootstocks as far as number of seeds and segments (carpels) per fruit, suggesting that rootstock species does not affect these characters.

These studies suggest in general that the fruit from chironja trees grafted on grapefruit rootstock is larger, but less sweet, than fruit from trees grafted on either sour orange or Cleopatra mandarine rootstocks.

\section{RESUMEN}

En las Subestaciones de Adjuntas e Isabela se sembraron chironjos injertados en patrones de toronjo del País, naranjo agrio y mandarino de la variedad Cleopatra en suelos de los tipos Alonso y Coto arcilloso, respectivamente. En el experimento de Isabela sólo se compararon como patrones el toronjo del País y el naranjo agrio.

El próposito de los experimentos era determinar qué efecto podrían tener los patrones en el peso de la fruta, peso de la cáscara, número de semillas y de gajos (carpelos) por fruta, y sólidos totales en solución (Brix). Los resultados más importantes fueron los siguientes:

En Adjuntas, el toronjo del País como patrón produjo frutas más grandes en los años 1962 y 1963 y cáscaras más pesadas en el 1963, que las producidas por el naranjo agrio y mandarino Cleopatra. El peso de la cáscara de la fruta en los chironjos injertados sobre naranjo agrio fue mayor en el 1962 que cuando se injertó sobre mandarino Cleopatra.

En el experimento de Isabela el Brix fue significativamente más alto en la fruta del chironjo injertado en un patrón de naranjo agrio que en la del injertado en un patrón de toronjo, sin que se observaran diferencias significativas en cuanto a los otros caracteres bajo estudio.

No se encontro diferencia significativa alguna entre los tres patrones estudiados con respecto al número de semillas y de gajos (carpelos) por fruta. Los resultados sugieren que el patrón no afecta estos dos caracteres de la fruta. 
En general, las chironjas producidas por los injertos sobre toronjo tenian un peso mayor pero eran menos dulce que las de los injertos hechos sobre naranjo agrio o mandarino.

\section{LITERATURE CITED}

1. Bitters, W. P., and Batchelor, L. D., Effect of rootstocks on the size of orange fruits, Proc. Amer. Soc. Hort. Sci. 57 : 133-41, 1951.

2. Cameron, J. W., Cole, Jr., D. and Naver, E. M., Fruit size in relation to seed number in the Valencia orange and some other citrus varieties, Proc. Amer Soc. Hort. Sci. 76: 170-80, 1960.

3. Commonwealth of Puerto Rico, Department of Agriculture, Facts and Figures on Puerto Rico's Agriculture, Special Publication No. 5, Santurce, Puerto. Rico, October 1968.

4. Moscoso, C. G., La Chironja, una nueva fruta puertorriqueña, Información oficial de la Estación Experimental Agricola No. 11, Univ. P.R. November 1956.

5. Moscoso, C. G., The Puerto Rico Chironja-New all-purpose citrus fruit, Econ. Bot. 12: 87-94, 1958.

6. Parker, E. R. and Jones, W. E., Orange fruit sizes in relation to potassium fertilization in a long-term experiment in California, Proc. Amer. Soc. Hort. Sci. 55: 101-13, 1950.

7. Rasmussen, G. K. and Smith, P. R., Effects of fertilizer rate, rootstock, and leaf age on the level of sulfur in citrus leaves, Proc. Amer. Soc. Sci. 71: 24147, 1958.

8. Rodríguez García, O., and Candela, J. B., Estadísticas Agrícolas de Puerto Rico 1935-1958, Agr. Exp. Sta. Univ. P.R., E. \& S.R. 53, 1959.

9. Shannon, L. M., and Zaphir, J., The relative influence of two citrus rootstock species upon plant growth and upon the inorganic composition of the scion, Amer. Soc. Hort. Sci. 71: 257-64, 1958.

10. Ting, S. V., Sites, J. W., and Deszyck, E. J., Measuring the internal color of Florids Red and Pink grapefruit with the Hunter Color and Color Difference Meter, Amer. Soc. Hort. Sei. 71: 265-70, 1958.

11. Ting, S. V., and Deszyck, E. J., The internal color and carotenoid pigments of Florida Red and Pink grapefruit, Proc. Amer. Soc. Hort. Sci. 71 : 271-7, 1958. 